\title{
THE GENETICS OF CEPAEA NEMORALIS
}

\author{
L. M. COOK \\ Deportment of Zoology, University of Manchester
}

Received I 2.x.66

\section{INTRODUCTION}

THE genetics of the polymorphic snail Cepaea nemoralis is now relatively well known. Much recent work has been designed to investigate the polymorphism and at the beginning of the century the species was used to study heredity by Arnold Lang (1912 and earlier). Breeding of C. nemoralis was begun by $\mathrm{Mr}$ A. W. Stelfox in 1909 and has been continued until the present time. The results of some early experiments were reported in rgr7 (Stelfox, 19r8) and one mating was discussed by Fisher and Diver (1934) in connection with an observation of their own. Since then very extensive studies by other authors, notably Lamotte (195I, 1954) and Gain et al. (Gain and Sheppard, 1952, 1957; Cain, King and Sheppard, 1960), have established or verified the principal properties of the system, rendering a full account of Stelfox's work unnecessary. Mr Stelfox has, however, very kindly allowed me to study the results of matings set up to investigate band modifying and band pigment reducing factors, which add considerably to present knowledge. The conclusions are reported here, together with an account of the evidence for the inheritance of shell size.

\section{MATERIAL AND METHODS}

The snails were collected from the wild as juveniles and reared to maturity on a diet which consisted principally of cabbage and oatmeal with an adequate supply of limestone. The offspring were raised in the same way, as a rule the parents being killed as soon as the next generation was considered well established. The complete results are presented in table I. Each experiment was given a number by Stelfox, which applied to all generations in that series. These are referred to as lineage numbers in table $\mathrm{I}$, and prefaced by the letter $\mathrm{S}$. The second column gives a mating number, added for reference purposes after the table was completed. The symbols used to describe the phenotypes are explained in the heading to the table. In the text the genetic nomenclature employed is that of Cain and Currey (1963).

\section{RESULTS}

(i) Punctate bands (S8, S16, S17, S29, S36)

In these pedigrees there are shells on which the bands are reduced in thickness at intervals along their length. This condition is known as var. punctata or var. interrupta and is also described by Lamotte (195I) by the term bandes pâles.

In the present material the factor behaves consistently in the different lineages, except for $\mathrm{S}_{3} 6$. It appears to be dominant ( $\mathrm{S} 8, \mathrm{~S}_{16} 6$, S29) and closely linked to colour and banding. This is shown by $\mathrm{Si}_{\mathbf{1}} 6$ and $\mathrm{S}_{29}$, in which there are no recombinants among the progeny of 


\section{TABLE I}

\section{List of Matings}

Localities:

$\begin{array}{llll}\text { An } & \text { Antrim. } & \text { Ros } & \text { Roscommon. } \\ \text { Cl } & \text { Clare. } & \text { SK } & \text { South Kerry. } \\ \text { Do } & \text { Down. } & \text { WD } & \text { West Donegal. } \\ \text { Fe } & \text { Fermanagh. } & \text { WM } & \text { West Mayo. }\end{array}$

Phenotype scoring:

$\begin{array}{ll}\mathrm{B} & \text { Brown. } \\ \mathrm{P} & \text { Pink. } \\ \mathrm{Y} & \text { Yellow. }\end{array}$

Y Yellow.

b Full banded. Occasional modifications such as fusions have not been noted. u Unbanded.

00300 Midbanded. A trace of band is recorded by a colon.

00345 Bands one and two absent, the others fully pigmented (listeria).

oo:45 Bands one and two absent, band 3 less strongly pigmented than four to five (donovania).

$\begin{array}{ll}\mathrm{pb} & \text { Punctate band. } \\ \text { lu } & \text { Hyalozonate bands and white lip. } \\ \text { al } & \text { White lip. } \\ \mathrm{cb} & \text { Cloudy band-see text. } \\ \text { unscorable } & \text { Shells which are too small for the data relevant to the context to be determined. } \\ \text { juv } & \text { Juvenile. }\end{array}$

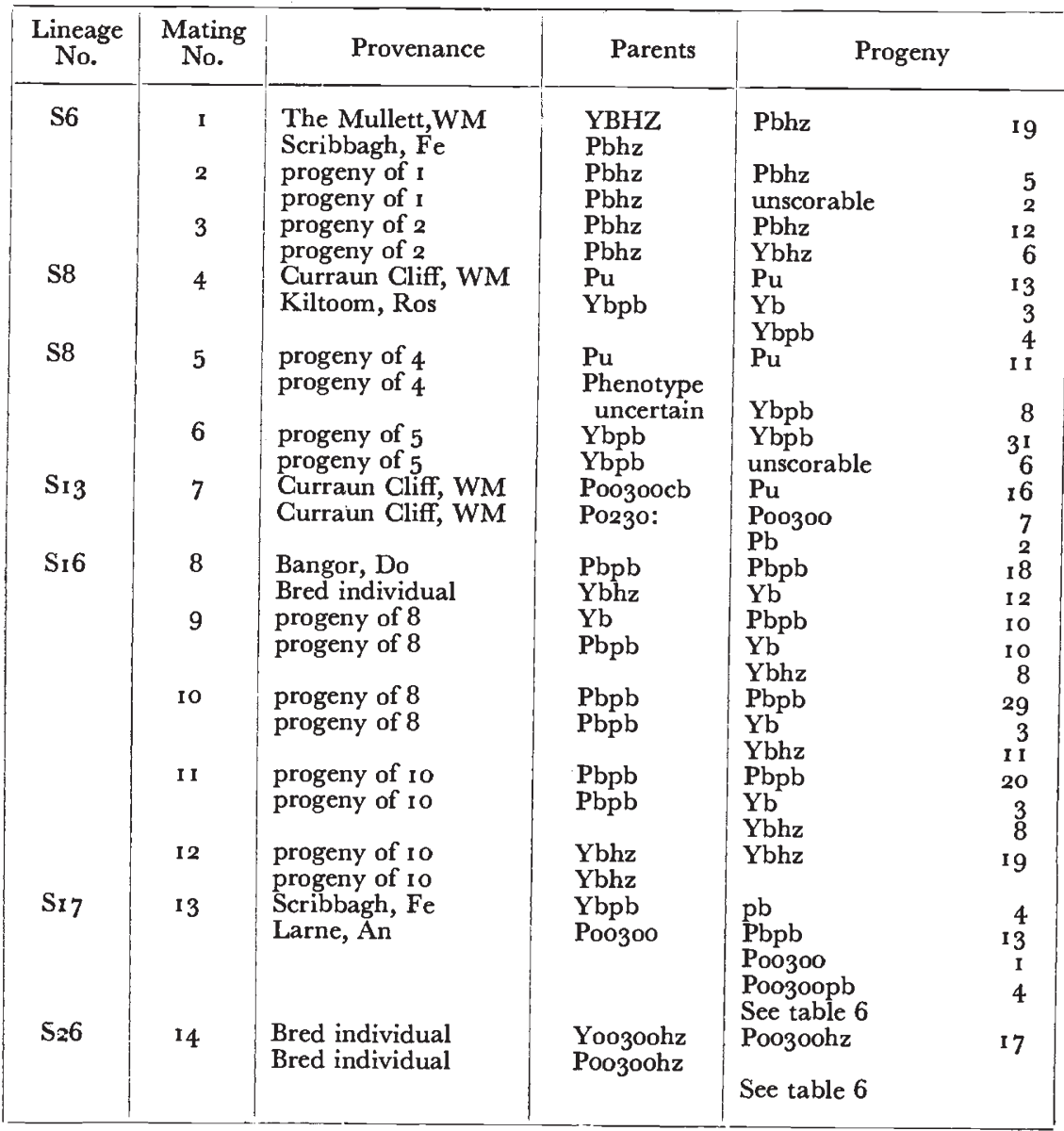


Table 1-continued

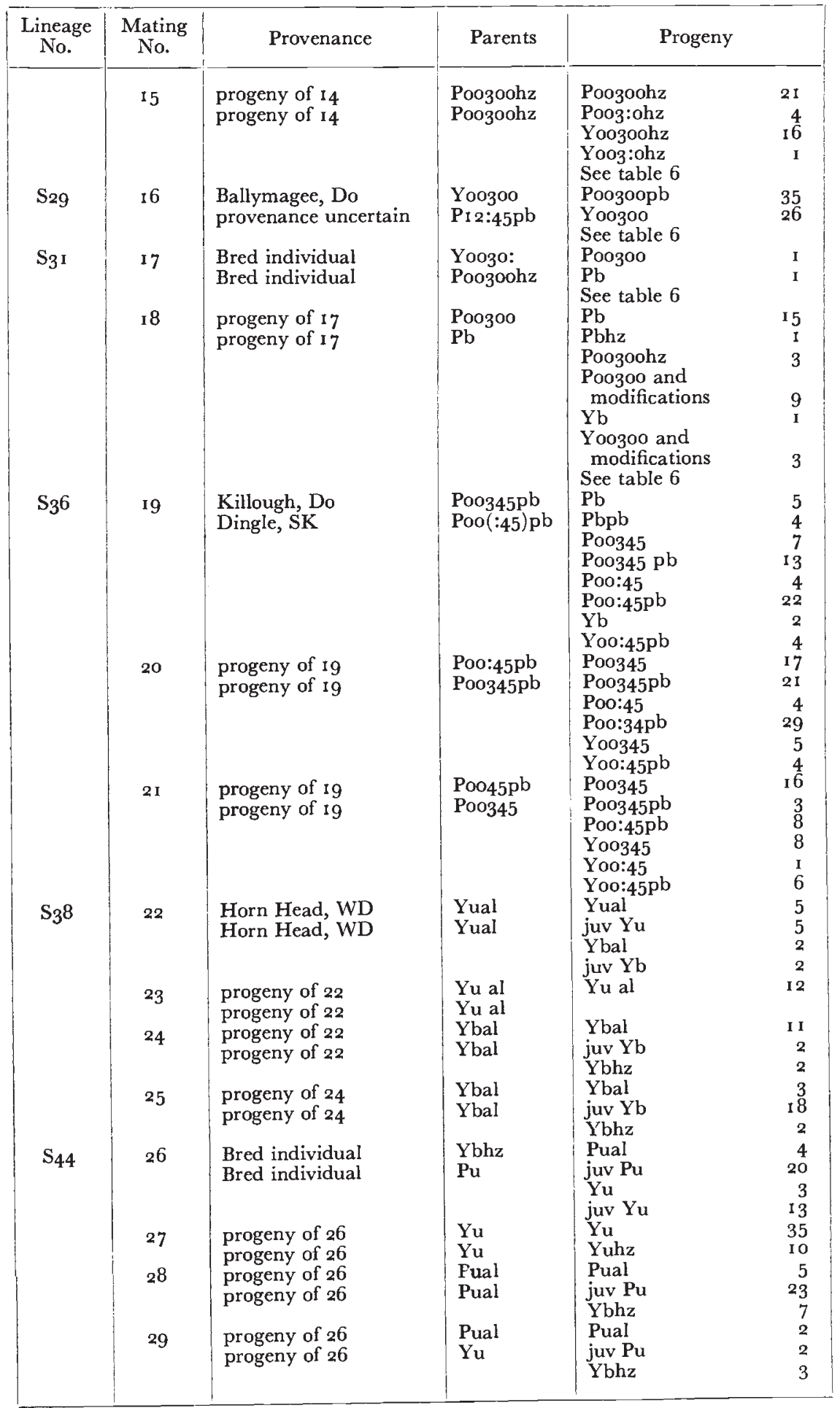


Table I-continued

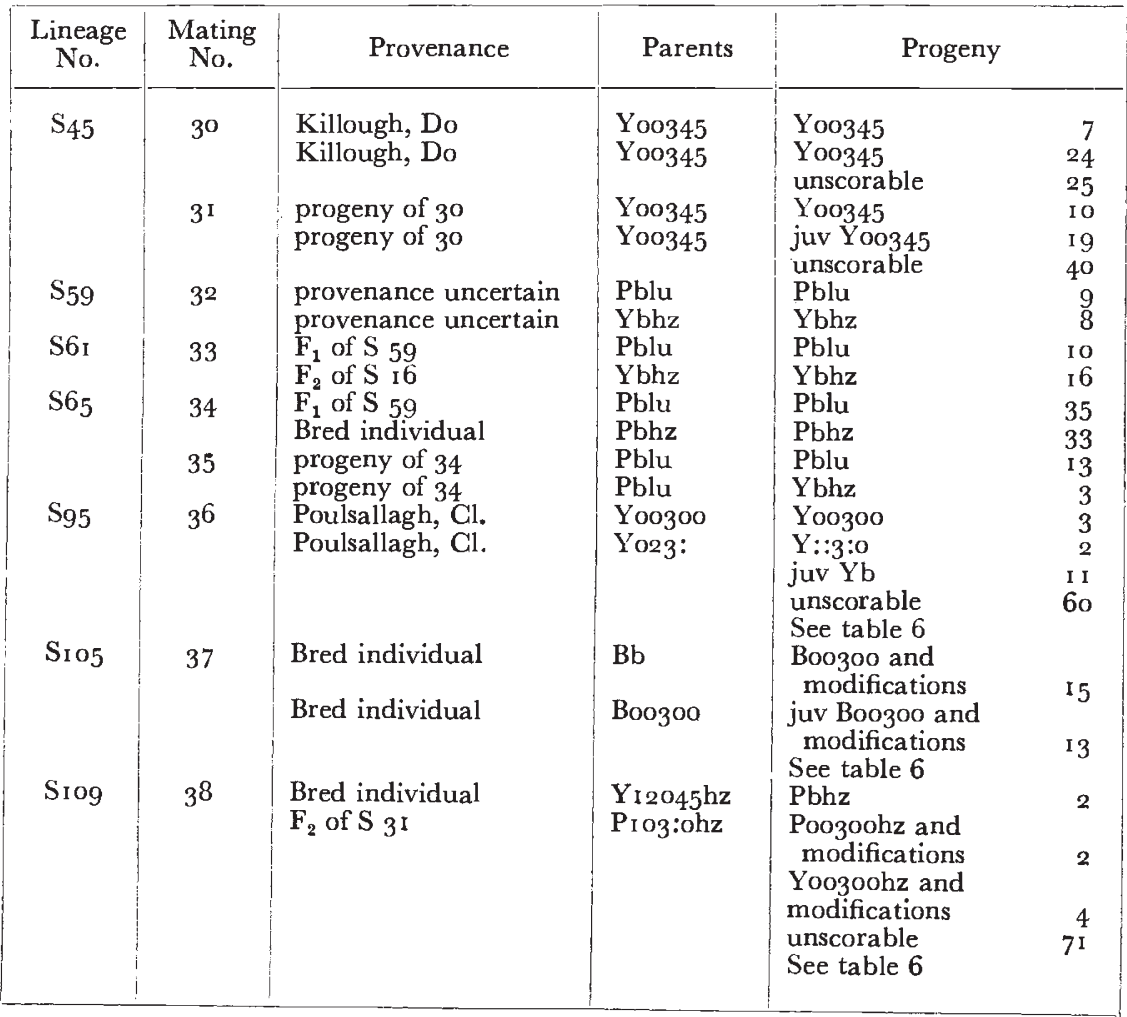

two $F_{2}$ crosses and two back crosses (table 2), suggesting that the crossover value cannot be more than about 3-4 per cent.

Lang (1912) showed that the similar character studied by him was dominant in effect. He crossed an unbanded individual to one with fully-pigmented bands (his Experiment A) and obtained unbanded

TABLE 2

Progeny segregating for colour and punctate bands

\begin{tabular}{|c|c|c|c|c|c|}
\hline Lineage & Mating & Pink punctate & Pink + & Yellow punctate & Yellow + \\
\hline $\begin{array}{c}\text { (A) } B a c k c \\
\text { S } 16 \\
\text { S } 29\end{array}$ & $\begin{array}{c}\text { coupling } \\
8 \\
\mathrm{I} 6\end{array}$ & $\begin{array}{l}\text { I } 8 \\
35\end{array}$ & $\begin{array}{l}0 \\
0\end{array}$ & $\begin{array}{l}0 \\
0\end{array}$ & $\begin{array}{l}\text { I2 } \\
26\end{array}$ \\
\hline Total & $\cdots$ & 53 & 0 & 0 & $3^{8}$ \\
\hline $\begin{array}{l}\text { (B) } F_{2} \operatorname{cou} \\
\text { S I } 6 \\
\text { S } 16\end{array}$ & $\begin{array}{l}\text { ro } \\
\text { I }\end{array}$ & $\begin{array}{l}29 \\
20\end{array}$ & $\begin{array}{l}\text { o } \\
\text { o }\end{array}$ & $\begin{array}{l}\circ \\
\text { o }\end{array}$ & $\begin{array}{l}\text { I4 } \\
\text { I I }\end{array}$ \\
\hline Total & $\cdots$ & 49 & o & 0 & 25 \\
\hline
\end{tabular}


and punctate banded progeny only (see fig. I). If banding and punctata are linked the unbanded parent could have been homozygous for punctata, as Lang assumed. In Experiment $\mathrm{G}$ one of the unbanded progeny is crossed to an unrelated full-banded. The offspring are unbanded and full banded in a $\mathrm{I}: \mathrm{I}$ ratio. In Experiment D, however, one of the unbanded progeny from $\mathrm{A}$ is crossed to an unrelated unbanded, the parents of which appear to have been a full banded and an unbanded. The offspring of this cross include punctata, so that recombination must have occurred in one of the parents since neither banded grandparent was punctata. In the absence of further information on the other lineage, we may suppose with Lang that the original unbanded in Experiment A was homozygous for punctata, so that the

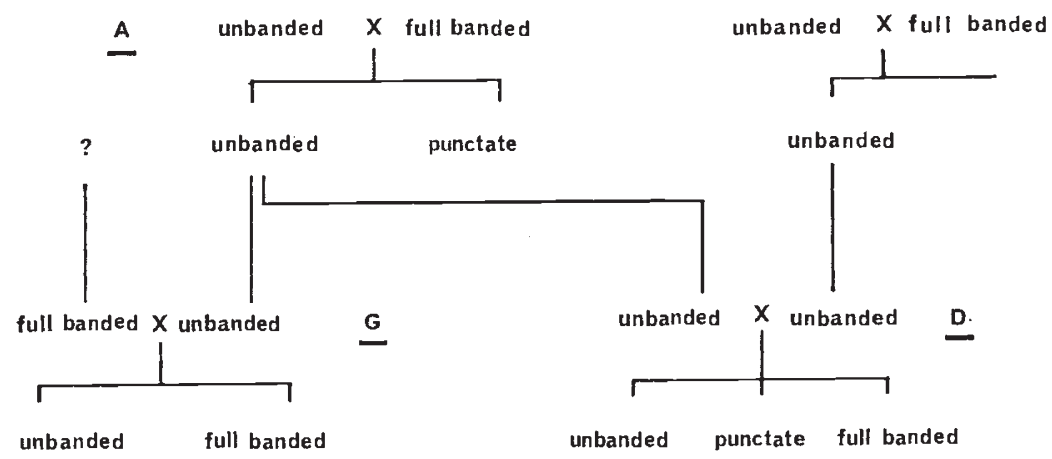

Fig. I.-The pedigree of three crosses made by Arnold Lang (Lang I9I2). For explanation see text.

unbanded progeny are heterozygous. Recombination in one of these would then give rise to the interrupteds in Experiment D. Unfortunately it is not stated how many progeny there were in each class, but if this explanation of the results is correct the outcome of Experiment $\mathrm{G}$ indicates relatively close linkage.

Lamotte (I95I) has also summarised Lang's results. He concluded that punctata is possibly independent of banding in view of the outcome of Experiment D. For the reasons outlined the data are compatible with the assumption of fairly close linkage. Some information on morph frequencies in wild populations, kindly supplied by Dr R. W. Arnold also agrees with this conclusion. Table 3 shows the numbers of punctate bandeds among pink and yellow bandeds from nine samples taken in southern France. There is a strong association between pink and punctata. The character is also present in the colonies on the Mullaghmore Peninsula, Co. Sligo (Cook and Peake, I962). The frequency is much lower than at Argelès, but here too there is a distinct excess of punctata in pinks compared with yellows (table 4).

The remaining cross showing the character is $\mathrm{S}_{3} 6$, where some problems of scoring arise. If both parents of mating i 9 carry punctata, as is suggested although this is difficult to score on the fused banded 
individual, then the two yellow full bandeds are recombinants. Similarly, recombination must be invoked to account for the result of

TABLE 3

Punctate bands among banded pinks and yellows in samples from Argelès, Pyrénées Orientales. Data of $R . W$. Arnold

\begin{tabular}{|c|c|c|c|c|}
\hline \multirow{2}{*}{ Colony No. } & \multicolumn{2}{|c|}{ Pink } & \multicolumn{2}{|c|}{ Yellow } \\
\hline & Full bands & Punctate bands & Full bands & Punctate bands \\
\hline I & 20 & 5 & I & 2 \\
\hline 2 & 7 & 0 & I & 5 \\
\hline 5 & 5 & 0 & I & I \\
\hline 9 & 33 & 2 & I & 8 \\
\hline 10 & I I & 0 & 4 & 4 \\
\hline I I & 19 & 0 & 0 & I \\
\hline 12 & $3^{8}$ & I & I & 7 \\
\hline 14 & I I & 0 & I & 2 \\
\hline I5 & 19 & 0 & 2 & I \\
\hline Total & 163 & 8 & 12 & $3^{I}$ \\
\hline
\end{tabular}

TABLE 4

Punctate bands in samples from the Mullaghmore Peninsula, Co. Sligo, Ireland. Details of the collection area will be found in Cook and Peake (1962)

\begin{tabular}{|c|c|c|c|c|}
\hline \multirow{2}{*}{ Colony } & \multicolumn{2}{|c|}{ Yellow } & \multicolumn{2}{|c|}{ Pink } \\
\hline & Full bands & Punctate bands & Full bands & Punctate bands \\
\hline 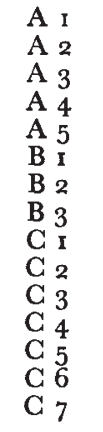 & $\begin{array}{r}21 \\
41 \\
102 \\
189 \\
38 \\
82 \\
14 \\
113 \\
31 \\
122 \\
48 \\
48 \\
46 \\
38 \\
13\end{array}$ & $\begin{array}{l}0 \\
1 \\
1 \\
5 \\
1 \\
0 \\
0 \\
1 \\
0 \\
0 \\
0 \\
0 \\
0 \\
0 \\
0\end{array}$ & $\begin{array}{r}4 \\
26 \\
53 \\
75 \\
10 \\
24 \\
2 \\
21 \\
5 \\
6 \\
19 \\
1 \\
4 \\
18 \\
18\end{array}$ & $\begin{array}{l}0 \\
1 \\
3 \\
4 \\
1 \\
0 \\
0 \\
0 \\
0 \\
7 \\
0 \\
3 \\
0 \\
0 \\
0\end{array}$ \\
\hline Total & 946 & 9 & 286 & I9 \\
\hline
\end{tabular}

matings 20 and 21. Segregation in all three matings appears to be disturbed, but the results from this lineage are not in accordance with those previously discussed (see Section iii). 
(ii) Hyalozonate bands, lurida and white peristome

(S6, S16, S26, S31, S38, S44, S59, S61, S65, S109)

At least two factors are known which remove all pigmentation from the affected area: a " hyalozonate" gene which leads to failure of pigment formation in both bands and peristome, and a "white lip" gene which produces an unpigmented peristome in the presence of fully pigmented bands. On an unbanded shell these phenotypes cannot be distinguished.

Lineages $\mathrm{S}_{16} 6, \mathrm{~S}_{31}$, and $\mathrm{S}_{44}$ show that hyalozonate banding is recessive, agreeing with the findings of Lang (I9II) and Cain, King and Sheppard (1960), and of Murray (1963) for the homologous condition in $G$. hortensis. Hyalozonate clearly belongs to the same

TABLE 5

Progeny of matings showing linkage between hyalozonate and colour and banding
$\mathrm{A}=$ Pink or unbanded
$\mathrm{B}=$ Non-hyalozonate (full pigmentation)
$\mathrm{a}=$ Yellow or banded
$\mathrm{b}=$ Hyalozonate

\begin{tabular}{|c|c|c|c|c|c|c|}
\hline Type of cross & Lineage & Mating & AB & $\mathrm{Ab}$ & $\mathrm{aB}$ & $\mathrm{ab}$ \\
\hline backcross repulsion & $\mathrm{S}_{44}$ & 26 & o & 4 & 3 & 0 \\
\hline $\begin{array}{l}\mathrm{F}_{2} \text { coupling } \\
\mathrm{F}_{2} \text { coupling } \\
\mathrm{F}_{2} \text { coupling } \\
\mathrm{F}_{2} \text { repulsion }\end{array}$ & 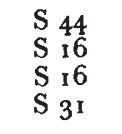 & $\begin{array}{l}27 \\
10 \\
11 \\
18\end{array}$ & $\begin{array}{l}29 \\
20 \\
24\end{array}$ & $\begin{array}{l}0 \\
0 \\
4\end{array}$ & $\begin{array}{l}0 \\
3 \\
3 \\
4\end{array}$ & $\begin{array}{r}10 \\
11 \\
8 \\
0\end{array}$ \\
\hline
\end{tabular}

linkage group as ground colour and banding, confirming the evidence at present available (Cain and Currey, 1963), but the linkage appears to be relatively loose (table 5). For all the crosses the single-factor segregation ratios agree with expectation, so that the matings may be combined to give a recombination value in the region of IO-I 5 per cent., with a lower 95 per cent. confidence limit of 4 per cent.

The evidence for a white lip gene which does not cause transparent bands comes from lineage $\mathrm{S}_{3} 8$. A cross between two white-lipped unbanded individuals (No. 22) produced some offspring with full band pigmentation. This would be impossible if white peristome was due only to their being homozygous for hyalozonate. However, when two of the offspring were sib-mated (No. 24) the progeny segregated for hyalozonate and fully pigmented bands in the presence of white lip, showing that both factors were present. This pattern was repeated in a mating of two of the full banded white-lipped individuals (25). Unfortunately, the matings in this series do not certainly show whether or not the genes exhibit complementation. If they do then both of the original parents must be homozygous for white-lip and one of them at least heterozygous for hyalozonate. This would normally be very unlikely, but it may not be so in the colony from which both individuals come, since both characters are sometimes present at high frequencies 
in Ireland. If the genes are not complementary then the hyalozonate white-lip heterozygote is indistinguishable from an individual homozygous for white-lip. There is evidence that the white-lip gene is recessive in effect (Cook, Ig66).

$\mathrm{S}_{59}$, S6 1 and $\mathrm{S}_{5}$ provide new information on segregation at the hyalozonate locus. The pedigrees begin with a cross between a hyalozonate yellow and an animal with an indistinct ground colour to the shell and slightly pigmented bands. The progeny segregate for a partial pigmentation of the bands which is most intense in the region of the varices and fades to the hyalozonate condition elsewhere. The lip is very slightly pigmented. These individuals appear to have a very pale pink ground colour.

One of the partially pigmented $F_{1}$ individuals from this cross is mated to a hyalozonate yellow in S6I, giving rise to so pinks with partially pigmented bands and 16 hyalozonate yellows. In $\mathrm{S}_{5}$, an $\mathrm{F}_{1}$ snail from $\mathrm{S}_{59}$ is crossed to a hyalozonate pink. The progeny segregated for partial pigmentation of bands in a $I: I$ ratio. The two latter crosses are between partially pigmented snails deriving this condition from $\mathrm{S}_{59}$, and hyalozonates from different unrelated lineages. Partial pigmentation is rare while hyalozonate is fairly common.

A gene is thus demonstrated which controls partial and somewhat irregular deposition of pigment in the bands. It is dominant to hyalozonate and shows no complementation with it. It therefore behaves in the same way as lurida in $C$. hortensis, which gene it resembles in phenotypic appearance (Murray, Ig63; Cook and Murray, r966). There is a dilute pigmentation factor (orange bands) in $C$. nemoralis which is non-allelic with hyalozonate (Cain, King and Sheppard, in preparation) and consequently not homologous with lurida in $C$. hortensis. The present investigation demonstrates the lurida gene in nemoralis which was predicted by Murray. In appearance it differs from orange banded in that lip pigmentation is very much less intense. Murray has also noted the suppression of ground colour by hyalozonate in pinks, so that the shell is white or extremely pale. The very diluted colouration of the lurida shells in these matings shows that suppression may also occur in the presence of this allele.

Three further matings (S6, $\mathrm{S}_{2} 6$ and $\mathrm{S}_{\mathrm{r}}$ og) were set up, beginning in I9ro, to investigate the inheritance of two varieties: citrinozonata and roseozonata. In all cases the segregations suggest that roseozonata is dominant to citrinozonata and non-complementary. The latter variety has a yellow shell with pale yellow translucent bands while the former is pink with rose-coloured translucent bands. It is quite possible that both varieties are hyalozonate banded yellows and pinks in which the band carries rather more of the ground colour than is usual, and segregation is for colour only. Since the ground colour may be partially or completely suppressed in the presence of hyalozonate, however, the possibility remains that roseozonata and citrinozonata may be due to at least one other gene which does not have this suppressing effect. 
(iii) Banding systems 00300 and 00345

(S13, S17, S31, S36, S45, S95, S105, S109)

Two major genes are known which cause reduction of bands. They are $M^{3}$, with the phenotype 0030o, and $U^{345}$ which leads to absence of the first two bands, 00345. Both factors are usually completely dominant and epistatic to five banded $\left(B^{B}\right)$. They are independent of ground colour and banding and of each other (Lamotte, I954; Cain and Sheppard, I957; Cain, King and Sheppard, I960). The affected bands are completely absent and those which remain are well defined and fully pigmented. In the present material there are some variants on this pattern.

In $\mathrm{S}_{17}$ and $\mathrm{S}_{29}$ oo3oo shells have the typical appearance of the phenotype, but in the other pedigrees traces of additional bands frequently appear. The variation is shown in table $6(A)$; where the colons indicate the presence of a faint or incomplete band which is usually interrupted in appearance. A trace of a thin additional band just below and very close to band 3 may also be present. The gene behaves in a way consistent with being dominant but having a variable expression, especially with respect to bands 4 and 5 . This is in marked contrast to the usual outcome of crosses involving oozoo, and may be due to the particular major factor involved, which could differ from the allele most usually studied in Britain and elsewhere. An alternative possibility is that the expression is modified by the genetic background of Irish snails; but snails with the phenotypes observed among the progeny occur sporadically in Britain, where the expression of 00300 in crosses is usually precise.

Table $6(B)$ gives data from two pedigrees on the inheritance of 00345. As indicated in section (i) lineage $\mathrm{S}_{3} 6$ is complicated by the presence of the interrupted band factor. It is difficult to make a complete scoring of the parents with confidence, but both have bands I and 2 absent showing that they carry at least one gene at the $U$ locus (Lamotte, I954). Among their offspring, however, there are full banded and 00345 individuals, so that both parents were heterozygous $U, U^{-}$, and individuals with the reduced number of bands fall into two categories. They either have band 3 at least as broad and as strongly pigmented as 4 and 5 (oo345) or else band 3 is thin and often indistinct, the most intense pigmentation being present in bands 4 and $5(00: 45)$. Only these two reduced-banded phenotypes are present (matings I9, 20 and 2I) so that one factor is dominant to the other. The results agree best with the hypothesis of dominance of 00:45 to 00345, although there is a consistent and nearly significant excess of 00345 among the progeny (for totals $\chi_{1}^{2}=3.55$ ). Both factors are dominant to $U^{-}$, so that there is in fact no critical evidence that they are at the same locus. The other lineage $\left(\mathrm{S}_{45}\right)$ behaves as if the 00345 gene is present.

In $\mathrm{S}_{1} 3$ one of the parents has the uncommon phenotype 0230:, where bands 2 and 3 are both strongly pigmented. To judge from the 
offspring this is a midbanded individual similar to those discussed above. The other parent has a continuous band of curious appearance. It is palely pigmented and thin, with a slight fascialbation below. Its continuous nature distinguishes it from punctata, and the colour is not that of orange banded. Nevertheless pigment is certainly present so that this is not the break in the ground colour sometimes found in the midband position on good unbanded shells. The progeny consist of

TABLE 6

The expression of bands in progeny of reduced banded individuals

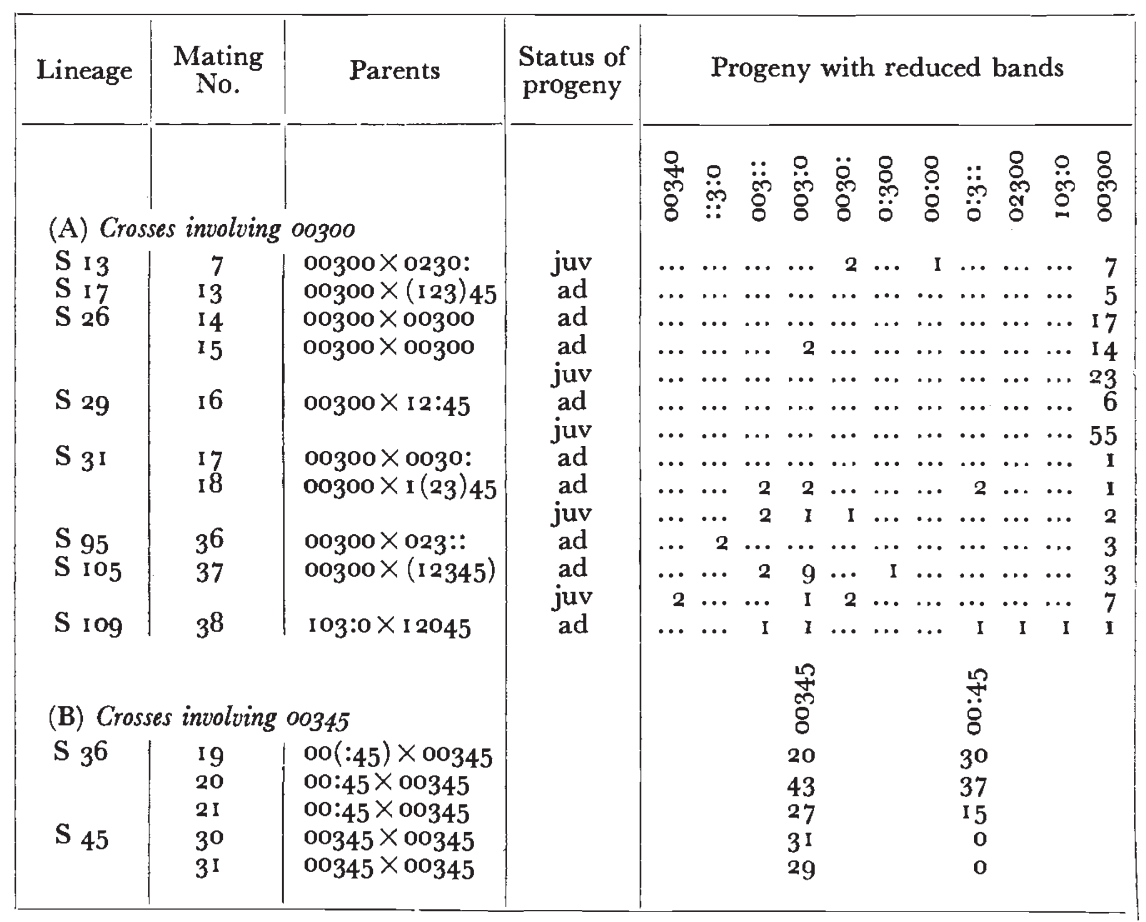

Io individuals with fully pigmented bands and i 6 which would probably all be scored as unbanded in a sample collected from the wild. Some of them have no trace of band but on others there is pigmentation in the central position fainter than but similar to that on the parent. Two simple hypotheses to explain these findings are $(a)$ that the parent is genetically full banded and heterozygous for an incompletely dominant band suppressor, or $(b)$ that it is heterozygous for an unbanded allele at the B locus which shows incomplete dominance. Neither of these situations has been recorded before.

\section{(iv) Shell size}

It has been noted (Cook and Peake, I960) that the offspring of the large-shelled individuals from the Galtee Mountains, Co. Tipperary, bred by A. W. S. (Stelfox, 1945) maintained the large size of their 
parents in the new environment. In table 7 the maximum breadth is given for snails collected from this region and their progeny, with similar measurements from a small-shelled pedigree for comparison.

TABLE 7

The breadth $(\mathrm{mm})$ of some large-shelled and small-shelled individuals and their progeny

\begin{tabular}{|c|c|c|c|c|c|c|}
\hline & \multicolumn{2}{|r|}{ Parents } & \multicolumn{2}{|r|}{$F_{1}$} & \multicolumn{2}{|r|}{$F_{2}$} \\
\hline & $\mathrm{N}$ & Mean & $\mathrm{N}$ & Mean & $\mathrm{N}$ & Mean \\
\hline $\begin{array}{l}\text { Galtee, Lough Muskry } \\
\text { Galtee, Lough Diheen } \\
\text { S } 45\end{array}$ & $\begin{array}{l}5 \\
6 \\
2\end{array}$ & $\begin{array}{l}24 \cdot 2 \pm 0 \cdot 5 \\
25 \cdot 0 \pm 1 \cdot 4 \\
21 \cdot 9 \pm 0 \cdot 01\end{array}$ & $\begin{array}{r}10 \\
1 \\
7\end{array}$ & $\begin{array}{l}24 \cdot 4 \pm \mathrm{I} \cdot \mathrm{I} \\
25 \cdot 3 \\
2 \mathrm{I} \cdot 5 \pm 0 \cdot 7\end{array}$ & $\begin{array}{c}6 \\
\cdots \\
9\end{array}$ & $\begin{array}{c}24 \cdot 4 \pm \mathrm{I} \cdot 2 \\
\ldots \\
2 \mathrm{I} \cdot 2 \pm \mathrm{I} \cdot \mathrm{O}\end{array}$ \\
\hline
\end{tabular}

It is clear that there is a strong hereditary component in the determination of shell dimensions. To estimate it with any degree of accuracy is difficult, however. Most of the matings have been made up from

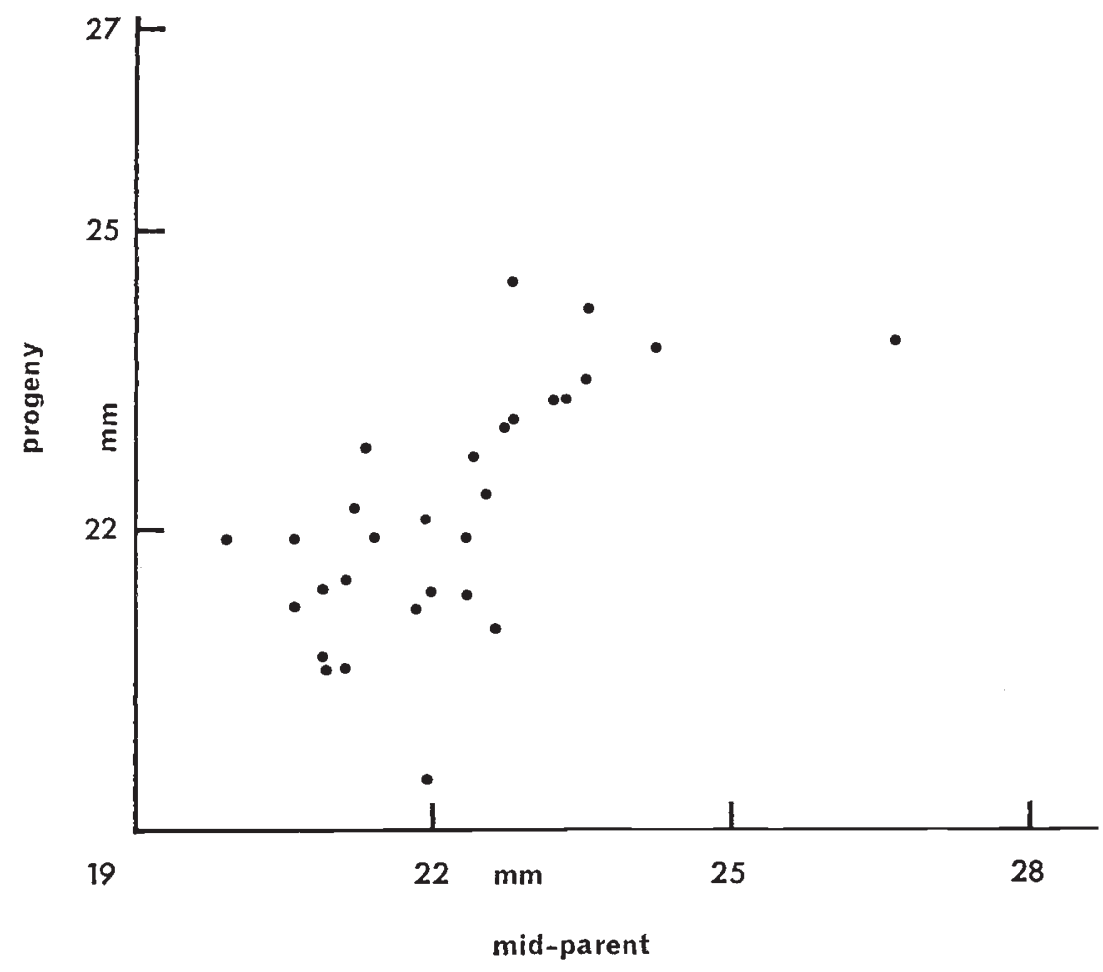

FIG. 2.-Shell Breadth. Regression of means of two progeny on midparental values.

within-colony crosses of wild juveniles or within-family crosses of their progeny. Since the variance of shell size in wild colonies is small (e.g. Cook and Peake, 1962) this has resulted in strongly assortative 
mating for size. For a sample of 20 parents collected as juveniles in the wild the correlation coefficient, $r$, is $0 \cdot 68$. Reeve (I955: see also Falconer, I960) points out that under such conditions the regression of progeny means on mid-parental values may still be an accurate estimation of heritability, provided of course that the variance of the parents is an adequate estimation of the total phenotypic variance. In the present instance the sample of parents which have been assortatively mated is probably a random one so far as size is concerned, because the characters investigated related to shell colour and pattern rather than to dimension. The environment of "wild" parents, however, was partly that of the very varied provenances in which they were collected and partly that of the rearing boxes; and it was entirely artificial for the $F_{1}$ and $F_{2}$ generations. These two environments may differ in their effects. Nevertheless, the offspring/mid-parent regression does at least indicate the order of heritability observed. Figure 2 shows the relation of the means of two progeny to mid-parent for 20 families with wild-collected parents and $9 \mathrm{~F}_{1}$ families. The progeny have been selected at random for measurement, and for the Lough Muskry family which was started by mass rearing from five individuals two have been selected at random to give the parental value. This procedure is likely to introduce little error since the parental shells are so similar in size. The calculated regression coefficient is 0.60 with a lower 95 per cent. confidence limit of 0.33 , indicating a heritability of about 60 per cent. This may be compared with the value of 70 per cent. for a similar but larger sample of Arianta arbustorum (Cook, I965), and is relatively high for characters under multifactorial control (compare Falconer, I96o).

\section{DISCUSSION}

The present material demonstrates a dominant gene for punctate bands which is closely linked to ground colour and banding and may be additional to the factor previously studied by other authors. There is also an allele for partial pigmentation (lurida) at the hyalozonate locus, which is linked to but relatively distant from that of ground colour (about io per cent. crossing over).

For animals which have a large number of chromosomes the establishment of linkage often presents difficulties (e.g. see Robinson, I956, I960). In Cepaea all the segregating characters which have been studied control aspects of the colour or pattern of the shell or of the body of the animal, and the majority of them have been shown to be linked (Cain, King and Sheppard, I96o; Cain and Currey, I963). There appears to be no doubt that ground colour, full banding, hyalozonate, spread bands and the punctate bands of Stelfox belong together in the same linkage group, and that mid-banded and 00345 are independent of them. Orange banded can perhaps also be put in the first category and darkening bands into the second. Thus, five out of seven loci, and possibly six out of nine, lie on the same 
chromosome. This has led Cain and Sheppard (1954; Cain, King and Sheppard, I96o) and others to suggest that intense epistatic selection has favoured firstly mechanisms transferring the genes to the same chromosome and subsequently an increasingly close linkage.

The haploid chromosome number in Cepaea nemoralis and $C$. hortensis is 22 (Perrot, I938; Mallett, I962). If we assume a random distribution of genes on the chromosomes the probability of finding six linked loci in a total of nine is less than $2 \times \mathrm{ro}^{-7}$. One of the chromosomes is more than double the size of the others, however. If the linkage group is on that chromosome the likelihood of the observed distribution becomes about $4 \times \mathbf{I O}^{-7}$. Among the larger globular helicids Cepaea nemoralis and $C$. hortensis show the most obvious and diverse visual polymorphism. The less variable species Helix aspersa and $H$. pomatia have 27 chromosomes while in Arianta arbustorum there are 3o. Within the genus Cepaea the two species in which variation is less notable, $C$. sylvatica and $C$. vindobonensis, have 25 (Perrot, I938). One of the chromosomes is larger than the rest but the difference is not so extreme as the differences between the larger metacentric and the others in $C$. nemoralis and $C$. hortensis.

This negative correspondence between chromosome number and apparent polymorphism breaks down when the family as a whole is considered, largely because there is a group (including Monacha cantiana and Hygromia striolata) which has a haploid number of 23 and is relatively invariable in appearance. It is interesting to note, nevertheless, that Cepaea nemoralis possesses almost the smallest recorded number in the group for a total of 43 species determined (Hygromia cinctella has 2I) and that an explanation other than random assortment of the genetic loci is required to account for the observed distribution of genes.

\section{SUMMARY}

I. The gene for punctate bands is dominant and closely linked to the colour and banding supergene (less than 3 per cent. recombination).

2. The hyalozonate band locus appears to be relatively loosely linked to colour and banding (about Io per cent.). A partial pigmentation allele (lurida) is present at the hyalozonate locus. It is dominant to hyalozonate and like it probably also has a suppressing effect on ground colour.

3. A oo345 gene causing extreme reduction of band 3 is distinguishable from the normal oo345 gene.

4. There is probably a dominant major gene, similar to midbanded in effect, which allows traces to remain of the bands completely suppressed by midbanded.

5. The heritability of shell size is estimated to be about 60 per cent.

Acknowledgments.-I am very grateful to Mrs N. Croze and Professors A. J. Cain, M. Lamotte, J. J. Murray and P. M. Sheppard for their helpful comments. 


\section{REFERENCES}

Cain, A. J., And currey, J. D. I963. Area effects in Cepaea. Phil. Trans. Roy. Soc. Lond., B, 246, I-8I.

CAIN, A. J., KING, J. M. B., AND SHEPPARD, P. м. 196o. New data on the genetics of polymorphism in the snail Cepaea nemoralis (L.) Genetics, 45, 393-4I I.

CAIN, A. J., AND SHEPPARD, P. M. 1952. The effects of natural selection on body colour in the land snail Cepaea nemoralis. Heredity, 6, 21 7-231.

CAIN, A. J., AND SHEPPARD, P. M. 1954. Natural selection in Cepaea. Genetics, 39, 89-II 6.

CAIN, A. J., AND SHEPPARD, P. M. I957. Some breeding experiments with Cepaea nemoralis (L.) 7. Genet. 55, 195-199.

Cook, L. M. 1965. Inheritance of shell size in the snail Arianta arbustorum. Evolution, rg, 86-94.

Cook, L. M. 1966. Notes on two colonies of Cepaea nemoralis (L.) polymorphic for white lip. 7. Conchol. 26, I25-1 30.

Cook, L. M., AND MURRAY, J. Ig66. New information on the inheritance of polymorphic characters in Cepaea hortensis (Gastropoda). 7. Heredity (in press).

COOK, L. M., AND PEAKE, J. F. I96o. A study of some populations of Cepaea nemoralis L. from the Dartry Mountains, Co. Sligo, Ireland. Proc. malac. Soc. Lond. 34, I-I I.

COOK, L. M., AND PEAKE, J. F. I962. Populations of Cepaea nemoralis L. from Mullaghmore Peninsula, Co. Sligo, Ireland, with a comparison with those from Annacoona, Dartry Mountains, Co. Sligo. Proc. Malac. Soc. Lond., 35, 7-1 3. FALCONER, D. A. I96o. Introduction to quantitative genetics. Oliver and Boyd, Edinburgh.

FISHER, R. A., AND DIVER, C. 1934. Crossing over in the land snail Cepaea nemoralis L. Nature, ${ }_{33}, 834$.

LAMOTTE, M. I95x. Recherches sur la structure génétique des populations naturelles de Cepaea nemoralis (L.). Bull. Biol. (Suppl.), 35, I-239.

LAMotTe, M. 1954. Sur le déterminisme génétique du polymorphisme chez Cepaea nemoralis L. Compt. Rend. Acad. Sci. Paris, 239, 365-367.

LANG, A. I9I I. Forgesetzte Vererbungstudien. Z. Ind. Abst. Vererb., 5, 97-I I8.

LANG, A. I912. Vererbungswissenchaftliche Miszellen. Z. Ind. Abst. Vererb., 8, 233-282.

MALLETT, G. E. 1962. A study of chromosome numbers in molluscs. Unpublished thesis.

MURRAY, J. 1963. The inheritance of some characters in Cepaea hortensis and Cepaea nemoralis (Gastropoda). Genetics, 48, 605-6I5.

PERROT, M. 1938. Etude de cytologie comparée chez les gastéropodes pulmonés. Rev. Suisse de Zool., 45, 487-566.

REEVE, E. C. R. 1955. (Discussion to paper by O. Kempthorne). Cold Spr. Harb. Symp. Quant. Biol., 20, 76-78.

ROBINSON, R. I956. A review of independent and linked segregation in the rabbit. J. Genet., 54, 358-369.

ROBINSON, R. I96o. A review of independent and linked segregation in the Norway rat. 7. Genet., 57, I 73-192.

STELFOX, A. W. I9I8. Researches into the hereditary characters of some of our British Mollusca. F. Conchol., 15, 268-275.

STElfox, A. w. I945. A large race of Cepaea nemoralis $L$. (and other Mollusca) at high altitudes in the Galtee Mountains, Co. Tipperary south. 7. Conchol., 22, I68. 